\title{
RELATÓRIO DO EDITOR DA REVISTA DE \\ SAÚDE PÚBLICA PARA 1983
}

\author{
REPORT OF THE EDITOR-IN-CHIEF OF THE REVISTA \\ DE SAÚDE PÜBLICA FOR 1983
}

A Revista de Saúde Pública completou, no exercício de 1983, seu 170 ano de publicação ininterrupta.

O aprimoramento da RSP, ao longo desses anos, tem sido preocupaçăo constante dos responsáveis pela sua edição. Para tanto, várias foram as modificações e acréscimos ocorridos. Entre eles o aperfeiçoamento do processo de seleção dos trabalhos; a inclusão e ampliaçđo do grupo de Membros Consultantes; introdução de novas seçōes com vistas a abrigar outros tipos de trabalho; ampliação do número de fontes bibliográficas para indexaçđ̃o dos artigos; mudanças na apresentação e aumento da periodicidade.

A Revista de Saúde Pública está aberta a contribuiçōes de especialistas nacionais, e também estrangeiros, refletindo pois a produção científica nacional no campo da Saúde Pública. Hoje, a RSP lidera as publicações periódicas especializadas nesse campo, no País.

A RSP é dirigida por Comissão de Publicações, constituida de 7 membros, sendo 5 da Faculdade e dois de outras instituiçóes universitárias.

Para seleção dos trabalhos, a Revista conta com a colaboração de grupo de Membros Consultantes, constituído de cientístas de alto gabarito, de várias instituições de ensino e pesquisa.

Cada trabalho entregue para publicação é submetido, em primeiro lugar, a um dos membros da Comissão de Publicaçōes, considerados, cada um deles, um Editor responsável por um campo de especialização da Saúde Pública. Recebido o trabalho, o Editor faz a primeira triagem, podendo, nesta fase, devolvê-lo aos autores no caso do mesmo não se enquadrar nas normas da RSP.

Aceito na primeira triagem, o trabalho é encaminhado a dois relatores, selecionados pelo Editor, dentre os membros do grupo de Membros Consultantes, ou mesmo enviado a outros especialistas, em certos casos. Os pareceres dos relatores são avaliados pelos Editores que emitem um terceiro parecer com a decisão, que poderá ser: aceito; aceito sob condiçōes; rejeitado com possibilidade de ser reformulado e reapresentado; e rejeitado. A decisðo final é tomada em conjunto pelos membros da Comissão de Publicações.

Foram submetidos a julgamento, no ano de 1983,81 artigos. 0 percentual de rejeição foi de $38,3 \%$. Quanto aos aprovados, num total de 50 artigos $(61,7 \%), 24(29,6 \%)$ estiveram condicionados a reformulaçőes propostas pelos relatores e 1 , que havia sido rejeitado, foi reapresentado e aprovado. Dos rejeitados, 9 ofereceram possibilidades de reformulaçóes, as quais nao foram aceitas pelos autores. 
A distribuição geográfica dos 50 trabalhos aceitos para publicação foi a seguinte: $64 \%$ do Estado de São Paulo e 36\% de outros Estados da Federação.

Quanto aos assuntos dos artigos verificou-se que o campo de maior interesse foi o da epidemiologia, com $38,6 \%$ dos artigos.

De acordo com as seçסes da RSP, $75,1 \%$ dos artigos foram publicados em "Artigos Originais"; 4,4\% "Revisð̃es"; 4,4\% "Atualizaçбes"; 8,1\% "Atualidades" e "Notas Epidemiológicas". Além disso, $0,9 \%$ foi dedicada a Editoriais, $4,6 \%$ a resenhas de livros técnico-cientí. ficos e 2,5\% a noticiário geral. O total de páginas publicadas foi de 517 .

Os artigos publicados são indexados pelas principais fontes bibliográficas especializadas em Saúde Pública e afins, nacionais e internacionais, num total de 16. Mais recentemente, a partir de 1982, a RSP passou a ser incluída no Social Science Citation Index e no Current Contents.

Para sua publicação, a RSP tem contado com recursos financeiros da FAPESP e CNPq/ FINEP, complementados pela Faculdade de Saúde Pública. E graças a esses recursos, a RSP tem tido sua periodicidade garantida.

A Comissão de Publicaçōes tem procurado diminuir o tempo de publicação dos artigos entre a data de recebimento e edição dos fascículos. Todavia, o processo de seleção e o cumprimento dos prazos por parte das firmas impressoras sđo fatores de atraso, muitas vezes difí. ceis de serem contornados. O tempo médio entre o recebimento dos trabalhos e sua publicação tem sido de 6 a 8 meses.

Os editores deixam aqui expresso seu agradecimento ao grupo de Membros Consultantes, e aos outros especialistas, que exerceram seu papel de relatores, com seriedade e rigor científico necessários. Ao mesmo tempo agradecem o eficiente trabalho de revisão e de secretaria, exercido pelos funcionários.

Os Editores esperam que a RSP continui percorrendo o caminho que vem palmilhando, no elevado objetivo de contribuir para o aprimoramento da Saúde Pública em nosso meio.

Oswaldo Paulo Forattini

Presidente da Comissão de Publicações 